\title{
AHMADIYYA: GROWTH AND DEVELOPMENT OF A PERSECUTED COMMUNITY
}

\author{
Abdul Rashid Moten
}

\begin{abstract}
Ahmadiyya, a group, founded in $19^{\text {th }}$ century India, has suffered fierce persecution in various parts of the Muslim world where governments have declared them to be non-Muslims. Despite opposition from mainstream Muslims, the movement continued its proselytising efforts and currently boasts millions of followers worldwide. Based on the documentary sources and other scholarly writings, this paper judges the claims made by the movement's founder, Mirza Ghulam Ahmad, analyses the consequences of the claims, and examines their proselytizing strategies. This paper found that the claims made by Mirza were not in accordance with the belief of mainstream Muslims, which led to their persecution. The reasons for their success in recruiting millions of members worldwide is to be found in their philanthropic activities, avoidance of violence and pursuit of peace inherent in their doctrine of jihad, exerting in the way of God, not by the sword but by the pen.
\end{abstract}

Keywords: Ahmadiyya, jihad, Mirza Ghulam Ahmad, Pakistan, philanthropy

\section{INTRODUCTION}

The Qur'an categorically mentions that Muhammad is the last in the line of the Prophets and that no prophet will follow him. Yet, there arose several individuals who claimed prophethood in Islam. Among the first to claim Prophecy was Musailama al-Kazzab, followed by many others including Mirza Hussein Ali Nuri who took the name Bahaullah (glory of God) and formed a new religion, the Bahai faith. Many false prophets continued to raise their heads occasionally but failed to make much impact until the ascendance of the non-Muslim intellectual, economic and political forces particularly in the $19^{\text {th }}$ century A.D. Iqbal (1990: 14) rightly points out:

... when the tide of life in a people begins to ebb, decadence itself becomes a source of inspiration, inspiring their poets, philosophers, saints, statesmen, and turning them into a class of apostles whose sole ministry is to glorify, by the force of a seductive art or logic, all that is ignoble and ugly in the life of their people.

A number of puritanical movements emerged after the fall of the Muslim Empire in India, which competed to organise the Muslim community in India. They often clashed with each other and, in their polemical publications, denounced their counterparts as deviants. Thus, the Sunni Muslim reformists emerging from seminaries in the Indian city of Deoband (the Deobandis) denounced another Sunni Muslim sub-sect, the Barelvi, of introducing questionable innovations in the practice and rituals of Islam. The Barelvi responded in kind. The two, however, agreed on accusing the Shi'as of heresy. Interestingly, the more conservative sections of all three sects in the region criticised the rationalist movements of the time led by scholars such as Sir Syed Ahmed Khan (1817-1898) and Syed Ameer Ali (18491928). 
Till about 1913, the Ahmadiyya movement was seen as a branch of the rationalist Muslim initiatives and Mirza Ghulam Ahmad (1835-1908) was considered as a modern redeemer of faith in India. Those who have accepted Mirza's claim call themselves Jama'at-eAhmadiyya or Ahmadiyya Muslim Jama'at. However, Mirza's claims to being one of the muhaddathun, inspired persons, and a zilli (shadowy, non-legislative) prophet (Mahzarnama, 2002: 108) are regarded as blasphemous by mainstream Sunni Muslims. Notwithstanding the criticisms levelled against the Ahmadis, the movement progressed and its adherents increased. This is due to the strategy of da'wah adopted by Mirza and followed by his followers.

This study analyses the emergence of the Ahmadis with a particular focus on Mirza Ghulam Ahmad, a prophet of a kind divinely appointed to revive and universally establish the law/ religion of Muhammad (SAW). This claim to the prophethood was made in the last phase of his life, prior to which, he made several other claims. This is followed by an examination of the consequences of founding the community and the persecutions the Ahmadis endured as a result. The third section analyses the strategies adopted by the community in recruiting and enlarging the membership of the community, which currently runs into millions.

\section{THE EMERGENCE AND GROWTH OF THE MOVEMENT}

The Ahmadiyya, pejoratively known as Qadiyani Movement, claims to represent "The True Islam". Its founder, Mirza Ghulam Ahmad, was born in Qadiyan in Gurdaspur District (Punjab, India) in "the last days of the Sikh rule in 1839 or 1840" (Ahmad, 1996: 10). According to several sources, his ancestors had been orthodox Sunni (Hanafi) Muslims. He secured a good education, good grounding in the Qur'an, studied Persian, Arabic, and logic. His father secured him an employment as a clerk with the Deputy Commissioner of Sialkot and he served in that capacity for four years. He left the job after finding many of his working colleagues "to be the devil's brethren in arrogance, waywardness, neglect of the religion and all kinds of other low morals" (Ahmad, 1996: 13).

According to his biographer, Mirza suffered from certain ailments: syncope, polyuria, and diabetes (Ali, 1973). He was timid, inattentive and had problems differentiating the left from right shoes (Nadvi, n.d.). His claim to prophethood began with the death of his father in 1876. According to Mirza, "Just as he was taken from the world, I started receiving Divine revelations with great intensity" (Ahmad, 1996: 17). However, in the 1880s, Mirza "blazed forth into an unprecedented whirl of public activity and wider publicity" (Bakhsh, 1993: 16) preaching Islam and championing the faith and convinced the Muslim community that he was a firm believer in Islam as enshrined in the Qur'an and the Sunnah. From the 1880s onwards, "Ahmad, the recluse, ascetic, became a public speaker, entering debates with members of the Arya Samaj, Christian missionaries and members of the ulama" (Valentine, 2008: 47). In December 1888, Mirza claimed himself to be a Mujaddid-i-Waqt (Revivalist of the Age) and one "Appointed by God" and invited people to render allegiance to him. The ceremony of initiation took place on $23^{\text {rd }}$ March 1889, which marked the formal beginning of the Ahmadis.

Mirza compared himself with Masih (Jesus), living like Masih - in poverty and humility. In 1891, he pronounced that Masih was dead, and claimed to be the Promised Messiah and the Promised Mehdi. In 1900, Mirza agreed to be addressed as Nabi and Rasul. He declared to be a prophet, sirat-i-siddiqui - one who is totally annihilated in the love of the prophet Muhammad (SAW). Later, he announced that he was the prophet of God. "I am the promised Messiah, I am the one who was named Nabiullah (prophet of Allah) by the leader of prophets and greeted him salam" (Ahmad, 1909: 51). In another place, he wrote: "According to complete 
shadow, I am the prophet and the messenger. I am that mirror which has the face of Prophet Muhammad and his complete reflection" (Ahmad, 1909: 11).

Mirza's claim to prophethood began with a challenge to the Qur'anic pronouncement that the Jews, contrary to their claim, did not kill Jesus, "the Messiah". The Qur'an (4:157) declares that "... They killed him not, nor did they crucify him, but Allah raised him up unto Himself...." He also repudiated the authentic traditions (ahadith) of Prophet Muhammad (SAW) that Christ would descend alive from heaven to complete his mission on earth in the cause of Islam. Mirza contended instead that Jesus died and was buried in Srinagar (Kashmir State, India). There was thus, according to him, no question of Christ himself descending from heaven but a mathil (or prototype) of Christ would appear in the future, and he himself, claimed to be that mathil.

Next, Mirza claimed himself to be the promised Messiah (or Christ) in his person, thus contradicting his earlier stand that only a mathil of Christ and not Christ himself was to appear in the future. Mirza also refuted the concept of the finality of the prophethood of Muhammad (SAW) and the Qur'anic verse (33:40) designating the Prophet (SAW) as Khatam al-nabiyyin (the last in the line of Prophets). Contrary to the majority Muslims' understanding of Khataman nabiyyin as "the seal, the greatest and the last of the prophets," Mirza interpreted it to mean that Muhammad (SAW) is "the seal" for authenticating all subsequent prophethood. To him, Muhammad (SAW) is "the last law-bearing prophet" (Dabbous, 1992: 6) and that there can still be lesser, like himself, non-legislative, zilli (shadowy) prophets (Mahzarnama, 2002: 108). He made it clear, as quoted by Friedman, that:

Law-bearing prophet can [ever] come [again]. A non-legislative prophet can come only if he is a member of the [Muslim] community. Accordingly, I am both a member of the [Muslim] community and a prophet. And my prophethood ... that is to say the divine discourse [with me] ... is a shadow of the prophethood of Muhammad. [...] My prophethood is nothing except that. It is the Muhammadi prophethood which became manifested in me (Friedman, 2003: 134).

Mirza thus held that there could be several people with the spiritual status of prophet Muhammad (SAW) and he himself claimed to be a prophet. His title muhaddath implies reception of divine messages and hence the religious authority of a special nature. He held that all those who did not believe in him were kafirs (non-believers) and prohibited funeral prayers for such infidels. To Mawdudi, belief in such a queer interpretation of the doctrine of Khatam al-nabiyyin alienated the followers of Mirza Ghulam Ahmad from the Muslims (Mawdudi, 1979). Mawdudi considered it to be "the most dangerous - of all the conspiracies hatched against Islam in modern times" (Mawdudi, 1975: 46). To poet-philosopher, Muhammad Iqbal, given the queer interpretation of the concept of the finality of the prophethood, the Muslims of India were fully justified in regarding the Ahmadis as a grave threat to their very existence as a united community. In June 1935, he advised the then British Government of India to "declare the Qadianis (Ahmadis) a separate community", distinct from the Muslims. Later in a letter to Jawaharlal Nehru, he wrote: "I have no doubt in my mind that the Qadianis are traitors, both to Islam and to India" (Iqbal, 1960: 188).

Most of the scholars in India in the $19^{\text {th }}$ or $20^{\text {th }}$ century agreed with Iqbal and others, and argued that the prophethood has been culminated and finalised in Muhammad (SAW) who 
was sent as the messenger, "as a bearer of glad tidings and a warner unto all mankind; but most of mankind do not know" (Qur'an, 34:28). They argued that the message Prophet Muhammad (SAW) brought then was extant in its original and pure form without any distortion or falsification. It remains comprehensive, pure and original as it was during the Prophetic period. The completion of the message through revelation to Muhammad (SAW) and its transmission worldwide leaves no room for a new prophet or a co-prophet to carry the divine message.

\section{CONSEQUENCES OF THE CLAIM TO PROPHETHOOD}

Given the fact that no new prophet was needed, Mirza claimed that he was the mujaddid of the century. Had he stopped at that level, his relationship with the generality of Muslims might not have been further strained. The problem started in November 1901 when Mirza put forward an unequivocal claim to be a full-fledged prophet of Allah (SWT). Responses to this claim came from two directions. One response came from among those who believed in his leadership and joined the Ahmadiyya movement. Subsequently, this group led by Maulvi Muhammad Ali and Khawaja Kamal al-Din, broke away in 1914, and formed the Ahmadiyya Anjuman Isha'at-iIslam Lahore (Lahore Ahmadiyya Association for the propagation of Islam). They accepted Mirza as the Promised Messiah and Mahdi as well as the Mujaddid (reformer) of the $14^{\text {th }}$ century (AH), but they rejected the idea that he was a nabi (prophet) or rasool (messenger) of Islam. They argued that Mirza did use these terms when referring to himself, but, they were used in a metaphorical sense.

The Ahmadis contended that the split in the community was bound to happen and Mirza Ghulam Ahmad had claimed to receive a revelation to that effect:

Today I have been shown [in a vision] that of the people present, there are some who have turned their backs towards me, and have stepped aside and, out of aversion, have turned their (faces) away from me (Ahmed, 2004: 1006).

This group claims to propagate Islam in its pure and original form to the whole world. Their motto is: "Allah is with us". This group is known as the Lahore Ahmadi because it left Qadian and established its headquarters in Lahore, Pakistan. Lahoris, unlike the Ahmadis, are not considered by the Muslim majority to be outside the pale of Islam. Sayyid Mawdudi in a letter in Urdu on $23^{\text {rd }}$ Muharram 1357 A.H. (25 th March 1938), wrote that “... the [Lahore] Ahmadi group is included within Islam ... we cannot issue any fatwa against them on the basis of the Shari'ah."

According to Simon Valentine (2008: 60), the Lahoris remain a very small community with 30,000 members worldwide, but, they have at least 17 missions around the world. They actively promote Islam, publish Islamic literature and built mosques. They built, among others, the Berlin mosque in Germany and the Mobarak mosque in the Netherlands. Queen Beatrix visited the Mobarak Mosque on $3^{\text {rd }}$ June 2006 to mark the 50th anniversary of the building of the mosque for which she was criticised by an independent Conservative MP, Geert Wilders, who is known as Islam's arch-nemesis in Europe (Pasic, 2006).

The second response came from mainstream Muslims who, led by Muslim scholars (Ulama'), declared Mirza's claim to be opposed to their categorical conception of khatm alnubuwwah, but more importantly, that Mirza had tainted the honour of Muhammad (SAW) by depriving him the absolute and everlasting authority as the last and final prophet. According to 
Abul Hasan Ali Nadwi (1980:125): Ahmadiyya "is a conspiracy which is specifically directed against the prophethood of Muhammad (SAW), and challenges the finality of Islam and the unity of Muslims." They also brushed aside Mirza's innovations of zilli and Baruzi prophethood as baseless. Consequently, they were condemned by Sunni Muslims as murtad (apostates) and zindique (heretics). To Nadwi, the Ahmadis had "obliterated the very borderlines which distinguish this ummah from all others" (Nadwi, 1980: 125). Thus began the stormy relationship between the Ahmadis and mainstream Sunni Islam. The Sunnis have deemed the Ahmadis as kafir (non-believer) and murtad (apostate). The Ahmadis retaliated by declaring those who did not believe in Mirza's claims to be kafir, thus severing religious and social relations with mainstream Muslims. These brought about a total rift between the Ahmadis and the rest of the Muslim world.

\section{THE PERSECUTION OF AHMADIS}

In 1953, Muslims in Pakistan demanded that the Ahmadiyya sect be regarded as a non-Muslim minority. They also demanded the removal of Sir Zafrullah Khan, a prominent Ahmadi, from his position as Foreign Minister of Pakistan. In this uprising, around ten thousand Muslims were killed. Several members of the ulama', including Mawdudi, were arrested and sentenced to death (which was later revoked). The anti-Ahmadi agitation continued throughout the 1960s and the 1970s. In April 1974, a major conference was held by the Muslim World League in Makkah which called the Ahmadi sect Kafir and beyond the pale of Islam. However, it was Zulfiqar Ali Bhutto, the Prime Minister of Pakistan, who referred the issue to the National Assembly which later enacted the Second Amendment to the Constitution of Pakistan on $7^{\text {th }}$ September 1974, declaring the Ahmadis to be "non-Muslims". General Muhammad Zia ulHaq, the President of Pakistan on $26^{\text {th }}$ April 1984, introduced Ordinance XX, which added Sections 298(b) and 298(c) to the Pakistani Penal Code (Valentine, 2008).

Section 298(c) of Ordinance XX, commonly referred to as the "anti-Ahmadi laws", prohibits the Ahmadis from calling themselves Muslims, preaching or propagating their religious beliefs, inviting others to accept Ahmadi teachings, or "insulting the religious feelings of Muslims". Article 298(c) has often been used against members of other religious minority groups including Christians. Pakistan's blasphemy law was again changed in 1986 - imposing life imprisonment on anyone insulting the Qur'an and the death penalty on anyone defiling the name of Prophet Muhammad.

Since independence in 1947, the Ahmadis have endured the persecution of various kinds. During the period between 1948-2007, a total of 87 Ahmadis were killed while 106 cases of attempted murder had been recorded. Their mosques had been burned, their graves desecrated, and their schools and colleges nationalised. According to a 2002 United States State Department report, 316 Ahmadis have been formally charged, since 1999, in criminal cases (including blasphemy) owing to their religion. Between 1999 and 2001, at least 24 Ahmadis were charged with blasphemy, either for wearing a shirt with an Islamic slogan or for distributing Ahmadi literature to the public. On $28^{\text {th }}$ May 2010, extremist Islamist militants attacked two Ahmadi mosques in central Pakistan, with guns, grenades, and suicide bombs killing 94 people, and injuring over a hundred people as a result (Human Rights Watch 2010, 2014). In short, the Ahmadis are denied the right to perform Hajj, their mosques vandalized, their graves destroyed, and the bodies of the deceased exhumed and removed from graveyards. From April 1984 to April 2004, according to official statistics, 756 Ahmadis were charged for displaying the kalimah; 37 for calling azan; 404 "for posing as Muslims", 131 for using Islamic epitaphs, 590 for preaching, 213 charged under the Blasphemy Laws and 845 "for 
various other cases against the Ahmadi under the anti-Ahmadi Ordinance 298 B/C" (HRCP, 2008; Ensor, 2007: 41).

Others followed the lead taken by Pakistan against the Ahmadis. In 1997, the President of Gambia, Mr. Yahya Abubakr, had officially declared the country's Ahmadi community a non-Muslim minority. Likewise, in 1998, the Fatwa Committee of Selangor, Malaysia, ruled that any individual who followed Ahmadi teachings was an apostate. The Mufti's Office in the Federal Territories claimed in 2008 that Mirza Ghulam was a British agent and alleged that the Ahmadiyya movement received Zionist support (Lee, 2011). Saudi Arabia officially bans the Ahmadis from entering the country and from performing the hajj (the pilgrimage to Makkah). In 2005, over 100 Ahmadis in Indonesia were evicted from their homes by a violent mob. In 2008, Indonesia enacted a Joint Ministerial decree that ordered for all Ahmadi Muslims to cease all public religious activities or face up to five years imprisonment (Human Rights Watch 2005/2008, 2014). According to Simon Ross Valentine (2008: 73), Ahmadis living in Bradford organized a 'Religions Founders Day', which was opposed by the Muslims. The Bradford Council for Mosques held a large demonstration leading to the cancellation of the event. A chemical attack was made on the Leamington Spa Mission House in September 2003. As a result, 15 people had to be decontaminated and quarantined.

\section{THE AHMADI STRATEGY FOR GROWTH AND DEVELOPMENT}

Undaunted by mounting criticisms at home, the Ahmadis decided to continue with their proselytizing effort at home and abroad. As Nadwi points out, they were determined "to become an independent world religion with its own Prophet, its own Companions, its own Caliphs, its own sacred places, its own history, its own personalities, and its own literature" (1984: 13). They claimed to be the true followers of Islam whose objective was nothing but the revival of Islam. They decided to embark upon jihad (struggle) not by the sword, but by the pen; not through violence, but through peaceful means. They put much emphasis on education and succeeded in producing highly educated people: scientists, engineers, and doctors in their ranks. They stressed on non-violence and inter-faith dialogues. Finally, they maintained the best of relations with those in authority in all the countries.

Ahmadis are committed to spread their message of "Islam" and thus to carry out jihad which, as defined by Mirza Ghulam Ahmad, is obligatory upon every Muslim. Islam, according to mainstream Muslim scholars, believes in peace, but permits the use of force in self-defence or to thwart any threat to Islam itself. Mirza Ghulam Ahmad believed in the Qur'anic principle that "there is no compulsion in religion" (Quran 2:256). He recognized the war "undertaken in self-defence", as "chastisement for aggression" and "those undertaken for the establishment of freedom of conscience that is to say for breaking up the strength of those who inflicted death upon such as accepted Islam" (Chaudhry, 1995: 7). He argued, however, that in contemporary times, jihad-bil-qalam (jihad with the pen) must replace jihad bil-saif (jihad with the sword) (Bakhsh, 1993: 36). In some cases, Mirza used the word jihad in the sense of "the cleansing of the souls". He believed in preaching Islam through "reasoning and heavenly signs." Mirza's adoption of the stance of pacifism and non-resistance to violence was meant, according to many scholars, to please the British colonialists and to receive their support in return. This was the strategy Mirza Ghulam Ahmad pursued during the colonial days.

Mirza was the loyal subject of the British government. Some scholars argued that Ahmadis were created by the British Secret Service to divide and weaken Muslims in India. According to Abul Hasan Ali Nadwi, "It has been historically and scholarly verified" that 
Ahmadis "had been brought into existence by Britain..." Nadwi cited Dr. Iqbal who wrote that the Ahmadiyya "is an organized and pre-plotted attempt to establish a new sect who pretends to have an apostle like Mohammad (SAW)" (Nadwi, 1972: 23). He quoted Mirza who wrote: "The greater part of my life has been spent supporting and defending the British Government ... I have always endeavoured that Muslims became true well-wishers of this Government and their hearts were purged of baseless traditions...." (Nadwi, 1980: 86). He "had lavishly praised the British, had recounted their benevolent achievements and services, had assured them of Muslim loyalty and had expressed his views against the doctrine of jihad. These trends persisted in his writings right up to the end of his life." (Nadwi, 1980: 86) In his Arabic treatise Nurul-Haq, Mirza declared that he was the citadel and amulet for protecting the British. In return, the Ahmadis received encouragement and patronage from the British rulers. Mirza Ghulam Ahmad was not swayed away by the criticisms levelled against him. Instead, he invited scholars to engage in debates on the purity of Islam as well as on his claim to be the protagonist of Islam. He travelled extensively across Northern India and held various debates with influential religious leaders. During the debates, he would ask for police presence to preserve peace.

Mirza's followers pursued this strategy of jihad with pen and peace with all in their pursuit to become the world religion. The Ahmadis borrowed freely from the strategies of the Christians" (Poston, 1992: 112). Like Christian missionaries, Ahmadis translated and disseminated the Qur'an, and provided educational activities and health services. MohammadArif observed such missionary work of Ahmadis in New York (Mohammad-Arif, 2002: 159). Ahmadis are quick to build their own mosques, which they turn into their local base or headquarters. Ahmadis have succeeded in building these mosques in a number of European cities as well as in cities in other non-Muslim lands. There are more than 500 Ahmadi mosques around the world (Haddad \& Smith, 1993: 49). Ahmadi communities are also known to be engaged in hospital building and setting up institutions of education. Ahmadis have made translations of the whole Qur'an into over 50 languages and translations of selected verses in over 100 languages, among them minor languages of Africa, Asia, and smaller European languages like Swedish, Lithuanian, Latvian, Catalonian, and even Yiddish. The activities of their missionaries around the world are controlled directly from the headquarters. The movement has its Missionary Training College in Rabwa to train professional $d a$ 'is.

Ahmadis invest heavily in education. It was Mirza Ghulam Ahmad who took the initiative in 1887 to establish an Islamic educational institution for the Ahmadi youth. The school was named Madrasah Ta'limul Islam, which was inaugurated on 1st January 1889. The school was subsequently upgraded to a college level. Later in 1906, Ta'limul-Islam College established a section, which came to be known as Jami'ah al-Ahmadiyya (often translated as Ahmadiyya University of Theology and Languages). Currently, Jami' ah al Ahmadiyya is an international Islamic seminary and educational institute with several campuses throughout Africa, Asia, Europe, and North America. It is the main centre of the Ahmadiyya Muslim Community for Islamic learning and the training of missionaries. Graduates may be appointed by the Caliph either as missionaries of the Community (often called Murrabi, Imam, or Mawlana) or as Qadis or Muftis of the Community with a specialisation in matters of fiqh (Islamic Jurisprudence). Some Jami'ah alumni have also become Islamic historians. There were over 1,300 graduates of the University working as missionaries throughout the world in 2008. Since then, the number of schools and colleges has multiplied.

Ahmadis are enjoined to be loyal subjects of the country in which they reside, regardless of its governing structure. The Ahmadiyya hierarchy promotes a strong duty to 
integrate into the society of the host environment. Simon R. Valentine (2008: 158) highlights a message given by the fourth Khalifa, Mirza Tahir Ahmad (1997) in his speech to students in Bradford, where he stated "It is imperative that we assimilate ourselves in the society that is our host". However, the Khalifah clarified, "I speak of an assimilation of values, not absorption brought about by blindly following each other. Thus, the thing to watch out for is that the exchange is of exquisiteness and not of unsightliness" (Valentine, 2008: 158). While assimilating themselves, they must keep their cultural values and traditions alive. These values include tenets such as the welfare of all kins, respect and care of the elders, a strong sense of community (religion and region based), and serving their families and community.

To achieve these ends, the community has established a strong presence in old and new mediums. Their aim is to integrate aspects of Western society, and at the same time strengthening and passing on cultural and religious norms. A wide variety of mediums have been harnessed in order to achieve this aim. First, the community has developed a strong online presence, which enables Ahmadi Muslims to transcend nations and live as a community worldwide. Through the Internet and satellite-TV, the community transcends all cultural, social, and political boundaries, and provides a strong presence that keeps the Ahmadi way of life sustainable in foreign lands. On social media sites like Facebook and Twitter, the Ahmadi community runs a tech-savvy campaign aimed at breaking stereotypes of Muslims - including a rejection of terrorism and advocacy for freedom of religion and empowerment of women.

\section{ACHIEVEMENTS OF AHMADI MOVEMENTS}

The overseas missionary activities of the Ahmadis began in the 1920s. Mufti Muhammad Sadiq was sent to North America in 1920 as the first Ahmadi missionary. "The following year, missionaries were sent to West Africa" (Gomez, 2005: 251). Mufti Sadiq, during the period between 1920-1922, succeeded in creating "small Ahmadi communities in New York City, Detroit, and Chicago" (Gomez, 2005: 251). The mission was reinvigorated in the 1930s and by 1940 "the Ahmadiyya boasted a global membership of almost 2 million - 5,000 to 10,000 of whom were in the United States." (Gomez, 2005: 252). Ahmadiyya movement is considered to be one of the precursors to the African-American Civil Rights Movement in America and was "arguably the most influential community in African-American Islam" until the 1950s. Many notable Jazz musicians converted to Ahmadism” (Gomez, 2005: 253).

Some of the first to convert to the Ahmadi movement were highly educated individuals from both secular and religious circles. These included many civil servants and also from the military. As of 2016, Ahmadi communities had been established in 209 countries. The Pew Research Centre reported in 2012 that over eight million Ahmadis spread across thirteen African nations. The World Christian Encyclopaedia found that Ahmadis had grown at a rate of 3.25 per cent between 1990 and 2000, and is the fastest growing religious community in the world (Barrett et. al., 2001). The largest concentrations of Ahmadis are found in South Asia and Africa. They are administering over 15,000 mosques and having millions of adherents worldwide. They have established over 650 schools offering both religious and secular educations in many parts of the world including over 150 in Ghana and a similar number in Sierra Leone. They fund vast humanitarian charitable programmes and run numerous free-toair international Islamic TV channels, radio stations and websites and translated the Qur'an into over 70 languages. They built and run over 40 world class hospitals in Africa and Asia.

Apparently, Ahmadis have succeeded in increasing its membership worldwide and have been well-received by governments at the international level. It is estimated that as of 
2009, there were at least 12 million Ahmadis worldwide and approximately 286,000 in Pakistan (Gregory and Valentine, 2009). The community has established its own hierarchy and infrastructure and claims to have established nothing less than the true Islam or "Islam in its pristine purity" (Chaudhry, 1996: 5). There exists a leader (amir) in each country who heads the executive body, which consists of National Secretaries of various departments such as finance, education, and religious training and preaching activities. The national executive body directs the activities of the organization at the local level. Members of the community believe in the ultimate triumph of their message, and membership of the community has increased manifold all over the world.

The movement was led by Mirza Masroor Ahmad in 2016 and holds the motto "Love for all, hatred for none". Mirza Masroor Ahmad regularly meets with heads of states and is often invited to speak at national parliaments such as the U.S. Capitol Hill, and the parliaments in Europe, the UK, New Zealand, the Netherlands and Ireland. He also regularly hosts interfaith events and peace symposiums. His book, The World Crisis and the Pathway to Peace, contains letters sent to numerous heads of states warning them of the threats faced by the world. The community is very active in faith outreach and has held hundreds of interfaith religious events and annual conventions in various countries. The $50^{\text {th }}$ Annual Convention held on $14^{\text {th }}$ August 2016, at Alton, Hampshire in UK, was attended by more than 38,000 people and the entire event was broadcast live on Muslim Television Ahmadiyya (MTA) International and streamed online. Mirza Masroor Ahmad spoke on the occasion stressing the need for peace. He said, "Today's disorder and terrorism is a result of the fact that people are distorting the teachings of religion and most certainly their hate-filled and evil actions do not have any link to the true teachings of Islam." He said Islam laid the foundation for peace by promoting true equality between peoples and nations (Staff, 2016).

The community maintains a good relationship with Israeli authorities as well as with the governments in the U.S., UK, Canada and others. In 1970, they built Mahmood Mosque on Mount Carmel in Kababir, Haifa, which acts as the National Headquarters for the Ahmadiyya Community in Israel. In Canada, it has about 50 local chapters across the country. In the U.S., Ahmadiyya Muslim community has about 60 local chapters and an estimate of 42 mosques all over the country. In 2014, the community obtained official representation through a new House caucus on Capitol Hill. This caucus represents the estimated 15,000 to 20,000 Ahmadis, constituting a small percentage of the three million Muslims living in America. They received the full support of President Barack Obama and Nancy Pelosi, the minority leader of the U.S. House of Representatives since 2011. To columnist Pamela Geller, "The White House has already been infiltrated ... Politicians are so desperate to find 'the moderate Muslims' that they'll do extraordinarily stupid things" (Senchez, 2014).

\section{CONCLUSION}

Ahmadis are the followers of Mirza Ghulam Ahmad who claimed, during various stages of his life, to be the Masih-i-maw'ud (the promised Messiah), the Mujaddid (the expected reformer), the Mahdi (the guided one), the Messiah (the promised anointed one), and a zilli prophet. Though the Ahmadis believe in all the five pillars and articles of faith required of Muslims, there are a few controversial beliefs which make them different from the rest of the Muslim community. In particular, the status of Mirza Ghulam Ahmed as the promised Messiah and the prophet is unacceptable to non-Ahmadi Muslims. Most Muslims consider Ahmadis to be heretics and leading Muslim scholars, ulama', pronounced a fatwa of kufr (non-belief). To the ulama', the Ahmadis are "a separate community (Ummah), parallel to Islam and the Ummah 
of Islam" (Nadwi, 1965: 101). As a result, they face persecution in many Muslim majority countries, especially in Pakistan where they have been denied the right of self-identification. The amendment made to the constitution of Pakistan in 1974 denuded the Ahmadis of their religious identity.

With the death of the first successor to Mirza Ghulam Ahmad, the movement split into two sects over the question of the finality of prophethood. The Lahore Ahmadiyya movement affirmed the absolute finality of prophethood and viewed itself as a reform movement. The main group, however, believed that Mirza indeed had been a prophet and its denial constitutes disbelief. Ahmadis claim to represent Islam in its pure and pristine form. They believe in Islam as the only religion free from error and on this basis, they try to proselytize energetically for Islam. They work hard to defend and extend Islam against the competition offered by adherents of other religions. Evidently, the membership of the community has swelled. This appears to be due, among other reasons, to their adherence to the concept of jihad, which is interpreted to mean exerting oneself in the way of Allah by pen and not by sword and through peaceful means. Their emphasis is on presenting Islam as a peaceful religion having nothing to do with violence and terror and emphasizing education as the only weapon for creating a sane, peaceful world. Most Ahmadis are highly educated and they promote interfaith dialogues with other religious groups to gain greater exposure to their religious viewpoints and to attain the confidence of foreign powers. They receive assistance from foreign quarters to construct mosques and to open schools and orphanages. They live peacefully in Israel as in Canada, the U.S. and other countries in the West and the East. They have been well received by major powers in the $21^{\text {st }}$ century. On the success of the Ahmadis, Dr. Muzammil Siddiqui, the Chairman of the Fiqh Council of North America, commented: "Ahmadi missionaries succeed because they are organized and they spread their message all over the world, while many of us are lazy and we don't present the authentic message of Islam with the same vigour and enthusiasm" (Fatwa, 2014).

\section{REFERENCES}

Ali, M. (2004). The founder of the Ahmadiyya movement. (3 ${ }^{\text {rd }}$ ed.). Newark: Ahmadiyya Anjuman Isha' at Islam.

Ali, M. (1973). The Ahmadiyya movement. Lahore: Ahmadiyya Anjuman Isha'at Islam.

Ahmad, B. (1994). Ahmadiyya moment: British-Jewish connections. Rawalpindi: Islamic Study Forum.

Ahmad, M. G. (1996). A brief sketch of my life. Lahore: Ahmadiyya Anjuman Isha'at Islam.

Ahmad, M. G. (1311A.H.). Hamamatul bushra. Sialkot: Punjab Press.

Ahmad, M. G. (1898). Kitabul bariyyah. QÉdiyÉn: Ziyaul Islam.

Ahmad, M. G. (1880). Barahine Ahmadiyya. Amritsar: Safire Hind Press.

Ahmad, M. G. (1909). Nuzule messiah. QÉdiyÉn: Ziyaul Islam. 
Ahmad, M. G. (2004). Tadhkirah: An English rendering of the revelations, dreams and visions of Hadrat Mirza Ghulam Ahmad of Qadian: The promised messiah and Mahdi. UK: Islam International Publications.

Bakhsh, K.S. (1993). The debt forgotten. Columbus, Ohio: Ahmadiyya Anjuman Isha'at Islam.

Barrett, D. B., George Thomas Kurian, G. T., \& Johnson, T. M. (Eds.) (2001). World Christian encyclopedia: A comparative survey of churches and religions in the modern world. New York: Oxford University Press.

Barni, I. (2003). Qadiyani Mazhab ka Ilmi Muhasbah (An academic analysis of QÉdiyÉnÊ religion). Mumbai: Maktaba al Haq.

Bashir, M. (n.d.). Haqiqatul Nubbuwat (The reality of prophethood). (n.p).

Bashir, M. (n.d.) Sirate Mahdi (The biography of promised Messiah). (n.p.).

Chaudhry, A. A. (1996). The promised messiah and Mahdi. Islamabad: Islam International Publications.

Dabbous, M. (1992). Al-Baseerat. UK: Ahmadiyya Publishing.

Ensor, J. (2007). Rabwah: A place for Martyrs? Report of the parliamentary human rights group mission to Pakistan into internal flight for Ahmadis. Parliamentary Human Rights Group, January.

Fatwa. (2014). Dr Muzammil Siqqiqi, “Ummah: The online Muslim community”. Retrieved from http://www.ummah.com/forum/showthread.php?240157-Mirza-Qadiani

Friedman, Y. (2003). The prophecy continues: Aspects of Ahmadi religious thought and its medieval background. New Delhi: Oxford University Press.

Gomez, M.A. (2005). The experience and legacy of African Muslims in the Americas. New York: Cambridge University Press.

Haddad, Y. Y. \& Smith, J. I. (1993). Mission to America: Five Islamic sectarian communities in North America. Gainesville: University Press of Florida.

Human Rights Watch 2005/2008, Retrieved from

http://www.hrw.org/sites/default/files/reports/wr2010.pdf [Accessed November 2, 2018).

'Human Rights Watch 2010' Available at http://www.hrw.org/news/2010/06/01/pakistanmassacre-minority-ahmadis [Accessed November 2, 2018).

Iqbal, M. (1960). From Sir Mohammad Iqbal, June 21, 1936. In A Bunch of old letters written mostly to Jawaharlal Nehru and some written by Him. Bombay: Asia Publishing House.

Iqbal, A. M. (1990). Islam and Ahmadism. Islamabad: Dawah Academy. 
Lee, P. "Malaysia's Ahmadis living dangerously" (2011, November 8), FMT News. Retrieved from http://www.freemalaysiatoday.com/category/nation/2011/11/08/

Mahzarnama. (2002). The Memorandum: submission by the Ahmadiyya Muslim Jama'at to the National Assembly of Pakistan regarding its basic tenets. Tilford: Islam International Publications Ltd.

Mawdudi, A. A. (1962). The finality of prophethood. Lahore: Islamic Publications.

Mawdudi, A. A. (1979). The Qadiyani problem. Lahore: Islamic Publications.

"Maudoodi's letter saying Lahore Ahmadiyya is a Muslim Group" at http://www.muslim.org /movement/maudoodi/letter.htm (Accessed December 12, 2016).

Mohammad-Arif, A. (2002). Salaam America: South Asian Muslims in New York. London: Anthem Press.

Nadwi, A. H. A. (n.d.). Qadianiyat: Mutal'ah awr Jaizah (Study and analysis of QÉdÊyÉnism). Karachi: Sh'uba Nashriyat-e-Islam.

Nadwi, A. H. A. (1980). Qadianism: A critical study (Zafar Ishaq Ansari tr.). Lucknow, India: Islamic Research and Publications.

Nadwi, A. H. A. (1972). "Lights on destructive movements" in Nadwi, Mawdudi and Kudr Hussein: Three essays on Qadiyanism. Mecca: The World Muslim League.

Pasic, T. 7 June 2006. "Wilders blasts Queen Beatrix over mosque visit".

Poston, L. (1992). Islamic Da 'wah in the West. New York: Oxford University Press. Staff, SW Londoner. (August 15, 2016).

"More than 584,000 people join Ahmadiyya Muslim Community as annual convention held". Retrieved from http://www.swlondoner.co.uk/584000-people-join-ahmadiyya-muslimcommunity-annual-convention-held/ (Accessed January 7, 2017).

U.S. Department of State, Bureau of Democracy, Human Rights and Labor. (2002).

Uthmani, M. S. (2013). Khatme Nubbuwat (Finality of prophethood) (6 $6^{\text {th }}$ eds). Deoband: All India Majlis Khatme Nubbuwat.

Valentine, S. R. (2008). Islam and the Ahmadiyya Jama 'at: History, belief, practices. Columbia University Press.

Zirvi, K. (2002). Welcome to Ahmadiyyat: The true Islam, Ahmadiyya movement in Islam. Silver Springs, U.S.: Islamic Publications Ltd. 